\title{
Perhe- JA LAPsityön ammatilliset ASIANTUNTIJUUDET KOKEMUSASIANTUNTIJUUDEN KONTEKSTISSA
}

\author{
Maritta Itäpuisto: YTT, tutkija, Lyväskylän ammattikorkeakoulu \\ Johanna Kiili: YTT, dosentti, yliopistonlebtori, Jyväskylän yliopisto \\ Kaisa Malinen: PsT, dosentti, vanhempi tutkija, Jyväskylän ammattikorkeakoulu \\ Johanna Moilanen: YTT, yliopistonlebtori, Jyväskylän yliopisto \\ Mari Punna: TtM, lehtori, Jyväskylän ammattikorkeakoulu \\ maritta.itapuisto@gmail.com;jobanna.j.kiili@jyu.fi; \\ kaisa.malinen@jamk.fi;johanna.s.moilanen@jju.fi; mari.punna@jamk.fi
}

Janus vol. 29 (3) 2021, 212-228

\section{Tiivistelmä}

Tutkimuksessa tarkastellaan ryhmähaastatteluaineiston avulla lapsi- ja perhepalveluiden ammattilaisten asiantuntijuutta suhteessa kokemusasiantuntijuuteen. Tutkimuksessa havaittiin kolme erilaista ammatillisen asiantuntijuuden muotoa. Ensimmäinen asiantuntijuuden muoto nimettiin yhteistyöasiantuntijuudeksi, mikä viittaa asiakkaiden kanssa yhteiseen tiedonmuodostukseen ja toimintaan. Toinen, perinteinen asiantuntijuus, taas pysyttelee tiukasti ammattiroolissa tarjoten vain rajoitetusti tilaa kokemusasiantuntijuudelle. Kolmatta ammatillisen asiantuntijuuden muotoa kutsutaan eettiseksi vartijuudeksi. Siinä painotus on käytännöllisesti ja konkreettisesti eettisyyden valvonnassa, mikä näkyy suhtautumisessa ammattilaisen ja kokemusasiantuntijan tehtäviin, ohjeistuksiin, pelisääntöihin ja riskeihin. Tulokset viittaavat siihen, että lapsi- ja perhepalveluiden ammattilaiset tuottavat eettisten kysymysten vartioinnin kautta uutta ammatillista roolia aiempien roolien oheen tai niiden tilalle. Tämä saattaa olla reaktio kokemusasiantuntijuuden aiheuttamaan paineeseen muokata työroolia.

\section{JOHDANTO}

Sosiaali- ja terveysalan asiantuntijatyöhön ovat viime vuosina vaikuttaneet tietotekniikan käytön ja etätyön lisääntyminen sekä hallinnon purkamisesta seurannut avustavien ja rutiinitöiden määrän kasvu. Lisäksi palveluiden markkinoistaminen sekä julkisen sektorin korostunut pyrkimys kustannussäästöihin ja laadun parantamiseen ovat muokanneet niin asiantuntijatyötä kuin potilaan tai asiakkaan roolia (esim. Sulik \& Eich-Krohm 2008; Kirkegaard 2020). Asiakasroolin muutoksessa passiivisesta palveluiden vastaanottajasta kehkeytyy aktiivinen toimija, tiedon tuottaja ja ammattilaisen rinnalla toimiva palveluiden yhteistuottaja (McLaughlin 2009; Toikko 2016, 292).
Tambuyzerin ja kumppaneiden (2014, 142) mukaan asiakasosallisuuden eri muodoista kokemusasiantuntijuus on merkittävin. Lyhyen - ja varsin tautologisen - määritelmän mukaan kokemusasiantuntijuus tarkoittaa asiantuntijuutta,jonka ihminen saavuttaa jossakin tietyssä asiassa oman kokemuksensa kautta.Vaikean ongelman, sairauden tai muun merkittävän elämäntapahtuman läpikäynnin ja siitä toipumisen lisäksi kokemusasiantuntijuuden syntymiseen tarvitaan kokemusta palveluiden käytöstä. Tällä tavoin kokemusasiantuntijuus on suhteessa myös virallisten organisaatioiden järjestämään ja ammattilaisten ohjaamaan tai johtamaan työskentelyyn, sen odotuksiin ja malleihin. (Needham 2007; Hietala \& Rissanen 2015,13 .) 
Kokemusasiantuntijuutta on tutkittu runsaasti erilaisiin fyysisiin sairauksiin sekä mielenterveys- ja päihdeongelmiin ja näiden hoitoon liittyen myös Suomessa (esim. Meriluoto 2018; Palukka ym. 2019; Soronen 2020). Toistaiseksi huomio on ollut lähes yksinomaan asiakkaissa ja potilaissa, kun taas kokemusasiantuntijoiden kanssa toimivien ammattilaisten näkökulmia ja etenkään sitä, miten kokemusasiantuntijuus vaikuttaa asiantuntijatyön tekemiseen, ei ole juuri tutkittu (ks. Arnetz ym. 2008; Caduri \& Weiss-Gal 2014, 2; Kirkegaard 2020). Tutkimustiedon vähäisyydestä huolimatta ammattilaisilta on vaadittu niin työkäytäntöjen ja asenteiden muutosta, kuin myös luomaan uudenlaisen suhteen ammatillisuuteen ja ammatti-identiteettiin (esim. Hirschovits-Gerz ym. 2019, 47; Pohjola ym. 2015).

Monessa maassa, Suomi mukaan lukien, myös julkinen valta on ohjannut ja normittanut asiakasosallisuuden lisäämistä (Sosiaali- ja terveysministeriö 2009; 2016). STM:n lapsi- ja perhepalveluiden muutosohjelmassa (2016, 8) lasten, nuorten ja vanhempien osallistuminen ja kokemusasiantuntijuus mainitaan yhtenä keskeisenä muutosohjelman lähtökohtana. Pösö (2018, 112) arvioikin, että kokemusasiantuntijuudella on vahva asema lastensuojelun kehittämisessä Suomessa (ks. myös Barkman ym. 2017). Kuitenkaan osallisuus ja kokemusasiantuntijuus eivät ole arjen työssä kattavasti mukana lasten, nuorten ja perheiden palveluissa (Kallinen ym. 2018, 15).

Tässä tutkimuksessa perehdytään siihen, miten ammattilaiset kuvaavat asiantuntijaroolia suhteessa kokemusasiantunti- juuteen lapsi- ja perhepalveluiden kontekstissa. Tutkimuksen aineisto kerättiin yhden maakunnan alueella sosiaali- ja terveysalan organisaatioissa sekä vapaaehtois- ja järjestökentällä toimivilta ammattilaisilta. Aineiston muodostavat kymmenen ryhmähaastattelua, joissa oli mukana yhteensä 36 henkilöä. Tutkimus on osa VerKo - Vertaistuen ja kokemusasiantuntijuuden paikka lapsi- ja perhepalveluissa -hanketta ja sen agenda on tieteellisen tiedon lisäämisen ohella tukea vertaistoiminnan ja kokemusasiantuntijuuden kehittämistä ja käyttöä lapsi- ja perhepalveluissa.

\section{Asiantuntijuus Ja \\ KOKEMUSASIANTUNTIJUUS}

Asiantuntijuutta on tutkittu vuosikymmeniä etenkin yhteiskuntatieteiden, psykologian ja kasvatustieteiden aloilla. Kunkin tieteenalan mukaisesti asiantuntijuuden määrittelyssä ovat painottuneet joko yksilön ominaisuudet ja kognitiiviset taidot tai sosiaaliset järjestelmät ja ihmisten väliset suhteet. Yksilönäkökulmasta tarkastellen asiantuntijaksi tullaan hankkimalla erityislaatuista tietoa, jonka avulla toiminta kehittyy ja muuttuu. Ammatilliseksi asiantuntijaksi kasvu vaatii vuosia kestävän kouluttautumisen, harjoittelun ja oppimisen, joiden myötä karttuvat tiedot ja taidot muodostavat erityisosaamisen. (Boshuizen ym. 2004, 4-6; Carr 2010, 22.)

Asiantuntijuutta voidaan tarkastella myös yhteiskunnallisena ilmiönä, johon kuuluu olennaisesti erilaisten tiedon lajien erottaminen. Tieto voidaan jakaa kolmeen päätyyppiin: asiantuntijatietoon, tutkimustietoon sekä 
arki- eli maallikkotietoon (esim. Bozeman 1993). Eri tiedon lajeja omaavat ihmisryhmät asettuvat keskenään hierarkkiseen yhteiskunnalliseen suhteeseen, jossa asiantuntijatietoon perustuvan osaamisen arvostus realisoituu asiantuntijoiden korkeana asemana ja arvovaltana yhteisöissään sekä muiden ihmisten heitä kohtaan osoittamana luottamuksena (Jakonen 2017, 12-15).

Suhtautuminen asiantuntijuuteen näyttää kuitenkin muuttuneen perustavanlaatuisesti viime vuosikymmeninä: yleisen yhteiskunnallisen demokratisoitumisen myötä asiantuntijuutta ja siihen liittyvää professionaalista valtaa on alettu kyseenalaistaa. Tasa-arvon nimissä vaaditaan myös muiden kuin asiantuntijoiden kuulemista ja huomioon ottamista päätöksenteossa (esim. Nowotny 2003, 151-152; Noorani 2013). Nämä muutokset ovat osa deprofessionaalistumista, johon kuuluu asiantuntijatiedon aseman heikkenemisen lisäksi kansalaisten ja asiantuntijoiden välisten valtasuhteiden muuttuminen ja jopa ammatillisen työn perusteiden kyseenalaistaminen (Rissanen 2015, 181).

Ammatillisen asiantuntijuuden heikkenemisen vastinparina maallikkojen erilaiset osallistumisen ja tietämisen muodot tulevat merkittävämmiksi. Etenkin kokemusasiantuntijuuden määrittelyssä juuri tieto on keskeisessä ja monitahoisessa roolissa. Kokemusasiantuntijan tiedon nähdään poikkeavan laadullisesti formaalista, ammatillisesta tiedosta (Pohjola ym. 2015; Rissanen 2015, 163-164; Haapakoski ym. 2018, 54; Soronen 2020). Se nähdään pragmaattisena ja holistisena, ainutlaatuiseen subjektiiviseen kokemukseen perustuvana erityisosaamisena (Oborn ym. 2019, 1317).

Empiirisessä tutkimuksessa ammattilaisten asiantuntijaroolien muutosta suhteessa kokemusasiantuntijuuteen on tarkasteltu toistaiseksi vähän. Sairaalaja klinikkaympäristöissä tehdyissä tutkimuksissa henkilöstön suhtautuminen mahdollisiin oman roolinsa muutoksiin tulee esiin osana asiakas- tai potilasosallisuuden haittoja ja hyötyjä koskevia kyselyjä. Potilaiden osallistumisen todetaan paitsi rikastuttavan työtä, niin myös samalla lisäävän ja vaikeuttavan sitä sekä vievän aikaa muilta potilailta (Arnetz ym. 2008; Légaré ym. 2008; Hämeenaho ym. 2019). Solbjorin ja Steinsbekkin (2011) tutkimuksessa terveysalan ammattilaiset näkivät asiakkaiden tiedon joko tukevan ammattilaisen tietoa tai olevan sille vaihtoehtoista, mutta myös olevan mahdollisesti epärelevanttia. Ammatillinen asiantuntijuus oli haastateltujen mukaan tärkeämpää kuin palvelukäyttäjien tieto.

McCann kumppaneineen (2008) havaitsi kyselytutkimuksessa psykiatristen laitospalveluiden henkilöstön suhtautumisen vaihtelevan sen mukaan, kuinka lähellä omaa perinteistä asiantuntijuutta maallikon toiminta on. Jos kyseessä on potilaan oma hoito, yleinen hoidon suunnittelu tai hallinnolliset kysymykset, suhtautuvat ammattilaiset potilaan mukana oloon positiivisesti. Jos taas kokemusasiantuntijuus puuttuu ammatillisen vastuun ytimeen, kuten potilaskertomusten kirjoittamiseen tai henkilökunnan koulutukseen, ovat asenteet negatiivisempia. Tutkijat tulkitsevat tämän johtuvan henkilöstön halusta pitää kiinni professionaalisesta dominanssista ja ammattirooleista, joita potilasosalli- 
suuden koetaan uhkaavan. (McCann ym. 2008; myös Kortteisto ym. 2018.)

Lääkäreiden asemaa erityisenä professiona, jonka pyrkimyksiin kuuluu saavuttaa tai säilyttää valta-asemaansa asiantuntijatiedon monopolisoinnilla, on tutkittu runsaasti (ks. Saarinen 2010, 24-25; Oborn ym. 2019, 1305). Saksalaisen lääketieteellisen yhteisön näkemyksiä tutkineen Dieterichin (2007, 281) mukaan suhde asiantuntija- ja maallikkotiedon välillä on epäsymmetrinen ja lääkärin asiantuntijastatus vahva. Hyvin informoitu moderni potilas voi kuormittaa ammattilaista haastaessaan tätä internetistä löytyneiden tietojen pohjalta sekä luomalla painetta vuorovaikutukselle. (Dieterich 2007.)

Sosiaalityön tieteellisessä keskustelussa asiakkaiden osallisuus ja tiedon demokratisoituminen ovat ajankohtaisia teemoja. Tutkimuksen ohella käytännön työn keskiöön ovat nousseet asiakkaiden autonomia ja voimaannuttaminen sekä jaetun asiantuntijuuden ja päätöksenteon ideaalit. Järvisen (2016) mukaan sosiaalityön asiakkaiden rooleissa tapahtuneiden muutosten ohella myös ammattilaisten tehtävät muotoutuvat. Ammattilaiset ovat alkaneet nähdä itsensä fasilitaattoreina ja valmentajina, jotka tukevat asiakkaan valitsemia tavoitteita ja ohjaavat heitä muutoksen ja kehittymisen tiellä.Tämä heijastuu ammattilaisten kielenkäytössä ja jopa siinä, ettei hoitoa haluta ohjata terapeuttisesti tiukemmin edes silloin, kun asiakas itse sitä toivoo. (Järvinen 2016, 59, 75-76.)

Robertsin ja Wolfsonin (2004) mukaan asiantuntijaroolin muutokset näkyvät myös psykiatrien työssä. Heidän asiantuntijuuteen perustuva auktoriteettinsa vähenee ja rooli muuttuu asiakkaiden muutosprosessien ohjaamiseksi ja tukemiseksi kohti itse valittuja tavoitteita. Kirkegaard $(2020,19)$ kokoaa ajatukset asiakasosallisuuden vaikutuksista ammattilaisrooleihin niin, että ammattilaisten pitää häivyttää työtään hienovaraisemmaksi tai näkymättömämmäksi. Asiantuntijatyön luonne muuttuu tämän myötä fasilitoinniksi, motivoinniksi, opettamiseksi, ohjaamiseksi sekä konfliktien ratkaisemiseksi. (McCann 2008; Storm ym. 2011; Kirkegaard 2020.)

Glentonin ja kollegoiden (2013) kirjallisuuskatsaus perustuu eri maissa tehtyihin selvityksiin ja suppeisiin tutkimuksiin vapaaehtoisten ja kokemusasiantuntijoiden työstä lapsi- ja perhepalveluissa. Tarkastelluissa tutkimuksissa ammattilaisten kuvataan suhtautuvan vapaaehtois- ja maallikkoauttajien osallistumiseen ja apuun toisaalta sitä arvostaen, toisaalta peläten ammatillisen auktoriteettinsa menettämistä.

\section{Aineisto Ja Metodi}

Tässä tutkimuksessa tarkastellaan ammattilaisten professionaalisia rooleja suhteessa kokemusasiantuntijuuteen lapsi- ja perhepalveluissa. Tutkimuksen keskiössä on asiantuntijuuden käsite, jonka kautta selvitetään, miten ammattilaiset konstruoivat formaalin asiantuntijuuden suhteessa kokemusasiantuntijuuteen ja kokemusasiantuntijoiden kanssa työskentelyyn.

Tutkimuksen haastattelumateriaali kerättiin touko- ja syyskuun 2019 välisenä aikana osana VerKo-hanketta. Aineisto kerättiin yhden maakunnan alueella 
julkisella ja kolmannella sektorilla toimivissa sosiaali- ja terveydenhuoltoalan lapsi-, nuoriso- ja perhepalveluiden organisaatioissa tai useampaa organisaatiota edustavassa verkostossa. Tutkijat pyysivät jo hankesuunnitelmavaiheessa organisaatioilta sitoumuksen aineistonkeruuseen ja kehittämisosuuteen osallistumiseen. Tutkimuslupa haettiin yhdeltä organisaatiolta. Muissa organisaatioissa lupa tutkimuksen toteuttamiselle myönnettiin ilman hakemista. Kunkin organisaation yhteyshenkilö kokosi ryhmähaastatteluihin vapaaehtoisia. Tutkijat ohjeistivat yhteyshenkilöitä pyytämään haastatteluihin ammattilaisia ja esimiehiä, joilla on erilaisia kokemuksia ja näkemyksï vertaistuesta ja kokemusasiantuntijuudesta. Tässä suhteessa haastateltu joukko onkin vaihteleva, sillä osa haastatelluista oli ainoastaan nähnyt kokemusasiantuntijan esityksen jonkun toisen organisaation järjestämässä tilaisuudessa, kun taas osa työskenteli organisaatiossa, jossa kokemusasiantuntijuus on yksi keskeinen työskentelyn ja toiminnan muoto.

Aineisto muodostuu kymmenestä ryhmähaastattelusta, joihin osallistui yhteensä 36 henkilöä. Ryhmien kesken osallistujat jakautuivat siten, että yhteen ryhmään osallistui 6 ja yhteen 5 henkilöä. 4 ja 3 hengen ryhmiä oli molempia kolme. Kahdessa haastatteluista oli mukana 2 henkeä. Haastatteluihin osallistuvilta pyydettiin aluksi kirjallinen suostumus osallistumiseen, eikä heiltä kerätty muita henkilötietoja. Ammattiryhmistä edustettuina ovat muun muassa sairaanhoitaja, sosiaalityöntekijä, sosiaaliohjaaja, toimintaterapeutti, varhaiskasvatuksen opettaja, terveyskeskuslääkäri, psykologi, palveluohjaa- ja, lähihoitaja, kuntoutuksenohjaaja ja sosionomi.

Haastatteluista kuusi tehtiin sosiaalialalla toimivien järjestöjen ammattilaisille, ja osallistujia näissä oli yhteensä 17.Yhdessä haastattelussa oli mukana ainoastaan terveydenhoidon ammattilaisia siten, että heitä oli yhteensä 4 henkeä. Kolme haastattelua tehtiin verkoston jäsenille, ja niissä oli mukana kaikkiaan 15 julkisen tai kolmannen sektorin edustajaa sosiaali- ja terveyspalveluista. Artikkelin tulosluvun haastattelulainauksissa puhujien taustaorganisaatiot ilmaistaan siten, että viitattaessa järjestössä tehtyyn haastatteluun on lainauksen lopussa suluissa "järjestö", terveydenhoidon alan ammattilaisten haastattelussa "terveys" sekä sosiaali- ja terveyspalveluiden verkostohaastatteluun viitattaessa "verkosto".

Kussakin haastattelussa oli mukana kaksi haastattelijaa, jotka vuorottelivat kysymysten tekemisessä. Kahdeksan haastattelua toteutettiin organisaatioiden tiloissa kasvokkain ja kaksi haastattelua videopuheluyhteydellä. Kuhunkin haastatteluun oli varattu 2 tuntia, ja niiden kesto vaihteli 1 tunnin 33 minuutin ja 1 tunnin 59 minuutin välillä. Osassa haastatteluista keskustelua rajoitettiin aikataulussa pysymiseksi tai kaikkia kysymyksïa ei ehditty käydä lävitse. Kussakin organisaatiossa toteutettiin yksi ryhmähaastattelu, lukuun ottamatta yhtä organisaatiota, jonka eri toimipisteet olivat mukana omilla ryhmillään.

Haastattelut toteutettiin teemahaastatteluna, jossa käsiteltiin ensimmäiseksi vertaistuki- ja kokemusasiantuntijatoimintaan liittyviä termejä ja käsitteitä 
sekä näiden termien kuvaamaa toimintaa omassa organisaatiossa. Muut pääteemat olivat henkilöstön vertaistuki- ja kokemusasiantuntijatoimintaan liittyvä osaaminen ja vaatimukset sekä näiden toimintojen johtaminen. Viimeinen haastatteluteemoista oli vertais- ja kokemusasiantuntijatoiminnalle nähdyt mahdollisuudet ja sen tuottamat riskit. Haastattelut nauhoitettiin. Tutkimusapulainen litteroi nauhoitteet sanatarkasti ja anonymisoi litteraatiot.

Heti haastattelulitteraatioihin tutustumisen alkaessa asiantuntijuuden teema tuli vahvasti esiin. Tutkijaryhmän keskustelussa päätettiin, että tämä teema otetaan tutkimuksen kohteeksi. Koko aineiston muutaman lukukerran jälkeen vastuututkija esikäsitteli aineiston poimien siitä kohdat, joissa puhutaan asiantuntijuudesta ja kokemusasiantuntijuudesta. Samassa yhteydessä hän poisti erilaiset tarpeettomat äännähdykset ja täytesanat sekä samojen sanojen toistot. Haastatellut käyttivät puhuessaan lukuisia eri käsitteitä, osin vaihdellen niitä haastattelun edetessä. Haastateltu saattaa aloittaa kertomalla, että kokemusasiantuntija toimii ryhmän vetäjänä ja myöhemmin samassa puheenvuorossa käyttää jotakin muuta termiä, kuten vaikkapa "ryhmän ohjaaja". Tällaisissa tapauksissa puheenvuoroa on tarkasteltu kokemusasiantuntijuuden kautta.

Aineistoa tarkastellaan kulttuurisena tuotteena, joka kertoo paitsi kunkin puhujan omista näkemyksistä tai omassa ammatissa saaduista kokemuksista, niin myös yleisistä yhteiskunnallisista asenteista. Juuri ryhmähaastatteluaineiston katsotaan soveltuvan erityisen hyvin tällaiseen tarkasteluun, sillä ihmiset tuottavat ryhmätilanteissa yhteis- tä, kulttuurista näkemystä yksittäisten mielipiteiden sijaan. (kts. Alasuutari 2011; Valtonen \& Viitanen 2020.)

Ensimmäisellä analyysikierroksella asiantuntijuutta ja kokemusasiantuntijuutta käsittelevät kohdat tiivistettiin lausetasolle, mihin sisältyi jo alustavaa merkitysten tulkintaa. Lausetason tiivistelmät koottiin erikseen sen mukaan, puhuttiinko niissä ammattilaisista ja heidän toiminnastaan vai kokemusasiantuntijoista. Kaikki lauseet analysoitiin purkaen ne yksittäisten lausumien tasolle. Analyysin edetessä tutkijaryhmän muut jäsenet tarkistivat ja kommentoivat vastaavan tutkijan analyysiä. Analyysin valmistuttua mukaan tuotiin haastateltuja ja organisaatioita koskevaa taustatietoa. Tätä tietoa käytettiin tulosten esittämisessä kontekstoiden niitä erityyppisiin organisaatioihin ja ammatteihin.

Analyysissä tunnistettiin kolme laajaa asiantuntijuuden muotoa, jotka eivät ole toisensa poissulkevia siten, että vain yksi niistä vallitsisi jossakin ammatissa tai työpaikalla. Tunnistetut asiantuntijuuden muodot nimettiin yhteistyöasiantuntijuudeksi, perinteiseksi asiantuntijuudeksi ja eettiseksi vartijuudeksi. Näitä tarkastellaan seuraavaksi kuvaten kunkin asiantuntijuuden piirteitä ja esiintymispaikkoja sekä suhdetta kokemusasiantuntijuuteen.

\section{TuloKseT}

\section{Yhteistyöasiantuntijuus}

Ensimmäinen aineistosta löytyneistä asiantuntijuuden muodoista, yhteistyöasiantuntijuus, näyttäytyy loogisesti 
osallistuvan asiakkaan vastinparina. Asiakkaiden osallisuuden ja toimijuuden lisääntyminen ja erityisesti kokemusasiantuntijoiden mukaan tulo työskentelyyn tarkoittaa ammattilaisen kannalta, että hänen täytyy riisua perinteistä asiantuntijan rooliaan ja opetella uusia toimintatapoja. Yhteistyöasiantuntijan pitää kulkea rinnalla tai hieman takana, kuten erikoistunutta osaamista vaativaa työtä tekevä ammattilainen seuraavassa tekstisitaatissa kuvaa:

(...) asiakas on se asiantuntija jo sillon siinä kuntoutuksessa ollessaankin ja itse sitä sitten ohjailee jollain tapaa toivon mukaan sinne oikeaan suuntaan ja kulkee siinä rinnalla ja ehkä vähän takanaki toivon mukaan aika piankin sitte jo, vähän vaan tuuppaamassa (H3, ryhmä 10, järjestö)

Ammattilaisen paikan määrittää nimenomaan asiakkaan asiantuntijuus, johon edellä lainattu puhuja viittaa. Varsinainen asiantuntemus perheen kysymyksissä nähdään siis olevan perheillä ja yksittäisillä ihmisillä itsellään sekä tiettyjen teemojen ympärille kokoontuneilla ryhmillä. Ammattilaisten asiantuntijuus lapsiperheiden kysymyksissä on haastateltujen mukaan muuttunut ja tullut tasavertaisemmaksi arkitiedon kanssa. Äärimmillään tämä voidaan kokea jopa asiantuntija-aseman menettämisenä, kuten seuraavassa sitaatissa:

Sinä lapsiperhearjen asiantuntija, toitotetaan ammattilaiselle, että koskaan sä et oo sillain asiantuntija kuitenkaan vaan perhe on itse asiantuntija arjessaan (H6, ryhmä 1 , verkosto)

Puheenvuoron perusteella voi siis päätellä, ettei yhteistyöasiantuntijuuden kehittyminen ole aina ammattilaisen näkökulmasta toivottua ja hallittua, etenkin jos tämä "ei koskaan" ole asiantuntija. Haastattelusta ei selviä, miltä suunnalta tulee "toitotus" joka toteaa, ettei ammattilainen ole asiantuntija perheiden arjen asioissa. Voi kuitenkin päätellä, että paine yhteistyöasiantuntijuudelle tulee jostakin ulko-, tai kenties jopa yläpuolelta. Yksi asiantuntijuuden luovuttamista vaativa taho tulee ilmi toisessa keskustelussa, jossa puhutaan asiantuntijavierailujen vähenemisestä ja rajoittamisesta erilaisissa lapsiperheiden tilaisuuksissa.

(...) ku mä olen tullu tänne töihin ni siel oli varmaan paljon enempi siinäkin ryhmässä vierailijoita, mut sit alko tulla sitä palautetta säännöllisesti, että he ei halua sinne, koska siinä ei pysty niinku keskittymään ja et se tavallaan vähän vaan häiritsee sitä heiän keskinäistä vertaistukee, että jotenkin tuntuu että siinä se on vielä tärkeempää se heiän keskinäinen sekä se lasten keskinäinen vertaistuki että heiän aikuisten, vanhempien (H1, ryhmä 3, järjestö)

Palveluja käyttävät perheet ovat siis kertojien mukaan ne, jotka toivovat ammatillisten asiantuntijoiden käyntien vähentämistä. Jos ryhmissä tai tilaisuuksissa käy asiantuntijavierailijoita, pitää heidän asiansa olla erityisen painavaa ja olennaista kuulijakunnan kannalta. Tämän haastatellut näkivät johtuvan siitä, että tietoa on nykyään helposti tarjolla kaikille ja kaikkialla. Asiakkaiden uskotaan tulevan palveluiden piiriin etsimään apua ryhmältä informaation kontekstualisoimiseen, ei niinkään saamaan tietoa ammatilliselta asiantuntijalta.

Yhteistyöasiantuntijuus voi olla ratkaisu ammatillisen asiantuntijuuden arvon 
heikkenemiselle. Sen kautta näkyväksi tulevat ammattilaisten tehtävät, jotka eivät sovellu asiakkaille. Yhteistyöasiantuntijuus konkretisoituu ammattilaiselle ensinnäkin fasilitaattorin roolissa (vrt. Järvinen 2016). Fasilitaattorina asiantuntija paitsi mahdollistaa työskentelyn yleensä, niin myös kunkin yksilön työskentelyn tälle mielekkäällä tavalla. Seuraava haastattelulainaus on tilanteesta, jossa keskustellaan uudenlaisista työnteon muodoista, joustavuudesta ja kaavamaisista vanhoista tavoista irti pääsemisestä.

Nii, joo, et meillä ei onneks oo semmosta, et kyl saa sit oikeesti lähtee toteuttaan, ja se on meiän vahvuus et me tehdään yhdessä asiakkaiden (termi anonymisoitu) kans että me ei, meiän asiantuntijuus on siinä et me saadaan heiät työskenteleen ja vedetään työpajoja ja fasilitoidaan niitä, mut me ei tehdä siitä puolesta (H3 ryhmä 4, järjestö)

Yhteistyöasiantuntijuudessa ammattilaiselle kuuluu vastuun kantaminen, mitä tehtävää ei voi siirtää kokemusasiantuntijoille. Ammattilainen on viime kädessä vastuussa asiakkaista myös sellaisessa ryhmätilanteessa, jossa kokemusasiantuntija toimii ryhmänvetäjänä. Seuraavassa tekstisitaatissa lapsi- ja perhepalveluiden verkoston jäsen pohtii tätä aihetta, käyttäen ammattilaisesta käsitettä "ulkopuolinen henkilö".

Jollain tavalla ehkä ois hyvä näissä, jos pietään ihan ryhmä että siellä on se ammattilainenkin mukana tilanteessa, että se voi olla tän vertaistukijan johdannaista, mut et siellä on kuitenki taustalla sitten vähän ulkopuolinen henkilö, joka voi tarvittaessa sitten ottaa siitä vähän koppia, jos tuntuu että se meinaa mennä vähän... (H2, ryhmä 6 , verkosto)
Ammattilaisen ulkopuolisuus viittaa sekä hänen asiantuntemuksensa laatuun, että siihen, ettei hänellä ajatella olevan vahvaa tunneyhteyttä ryhmän jäseniin. Nämä molemmat ovat etu, sillä ollessaan etäämmällä käsiteltävästä aiheesta, ammattilainen pystyy objektiivisemmin seuraamaan tilanteen kehittymistä ja puuttumaan, jos tilanne uhkaa ajautua hallitsemattomaksi.

\section{Perinteinen asiantuntijuus}

Yhteistyöasiantuntijuudessa muovautuvan, haastetuksi tulevan tai osin jopa katoavan ammatillisen asiantuntijuuden lisäksi aineistossa näkyy selvästi, että myös perinteistä asiantuntijaroolia halutaan pitää yllä. Perinteisen asiantuntijuuden muodon ytimessä ovat ammattilaisen ja asiakkaan tai potilaan erilliset roolit, joissa ammattilaiselle kuuluu asioiden tietäminen ja ratkaisun löytäminen asiakkaan ongelmaan.

Haastateltujen kertoman mukaan myös kokemusasiantuntijoiden kanssa työskenneltäessä tai suhteessa heihin teoreettinen ja menetelmällinen, sekä tiettyä asiantuntemuksen alaa koskeva laaja tieto ja osaaminen kuuluvat edelleen ammattilaisille. Myös niissä tutkituissa organisaatioissa, joissa kokemusasiantuntijuus on merkittävä toiminnan muoto, on välineiden kehittäminen, kysymysten peilaaminen teoreettiseen tietoon sekä luentomateriaalien valmistaminen ammattilaisten aluetta.

Erityisten tai haastavien ongelmatilanteiden hoitamisen haastatellut kuvasivat kuuluvan yksinomaan ammattilaisille. Etenkin tilanteissa, joissa tarvitaan ammatillista harkintavaltaa, kontrollia ja 
päätöksentekoa esimerkiksi palveluista tai hoidosta, on ammatillinen asiantuntijuus legitiimi. Vaikka kokemusasiantuntijoiden yksi perustehtävä on erilaisissa koulutustilaisuuksissa puhuminen, tarvitaan aineiston mukaan joissakin koulutustehtävissä ammattilaista. Seuraavassa lainauksessa haastateltu kertoo esimerkin tästä:

(..) mutta on myös semmosia vertaisviikonloppuja, joissa pitää olla ihan oikeesti ammattilainen kouluttaja, esimerkiks riittävän hyvä sitten kieli, elikkä kun tää tilanne (yksilöivä termi poistettu) päättyny perheessä ni se voi olla sen verran traumaattinen ( $\mathrm{H} 2$ ryhmä 4 , järjestö)

Se, kuinka laaja ammattilaisen perinteinen asiantuntijuus on, näyttää liittyvän asiantuntijuuden alaan. Sosiaali- tai kasvatusalalla ammattilaisen perinteisen asiantuntijuuden kuvataan rajoittuvan melko rajattuihin tehtäviin ja tilanteisiin. Sen sijaan lääketieteen ammattilainen esitetään osassa ryhmäkeskusteluja kokonaisvaltaisena perinteisenä asiantuntijana. Seuraavassa tekstisitaatissa ryhmä keskustelee siitä, miten lääkäri heidän kokemuksensa mukaan suhtautuu kokemusasiantuntijan vierailuun henkilökunnan kokouksessa:

H4: (...) yleensäki kuuntelee vaikka lääkäreitä tai muita niin he ei välttämättä halua omiin palavereihisa et joku tulee esittäytymäan et hän on sen ja sen alan guru, tai tämmönen

Haastattelija: Osaatko sanoo mihin se liittyy, mistä se tulee se semmonen ei-innokkuus?

H4: Onks henkilökunta sit jotenkin niin läaketieteellisesti suuntautunut

H2: Se on häiriötekijä, rasite siinä, sille pitää jotain sanoo, niinkun jos tulla tupsah- taa johonki esittäytymään. Minä olen ollu tämmösessä palaverissa, lääkäri sano sen jälkeen että hittolainen, mitä se täällä teki. Nii, että ei ymmärtäny ollenkaan. (ryhmä 2 , terveys)

Yllä olevassa keskustelussa puhujat eivät kuvaa itse suhtautuvansa epäilevästi kokemusasiantuntijoiden vierailuihin henkilökunnan kokouksissa, vaan varautunut asenne tiivistyy kahdessa eri kohdassa lääkärikuntaan, joka "ei halua" kokemusasiantuntijoita kokouksiin tai "ei ymmärrä" mitä he tekevät niissä. Syyksi sille, että kokemusasiantuntijan osallistuminen kokoukseen koettiin häiriönä, yksi keskusteluun osallistuneista taas ehdottaa henkilökunnan "lääketieteellistä suuntautuneisuutta".

Kuten aiemmassa tutkimuksessa (esim. McCann ym. 2008) on havaittu, suhtautuvat lääkärit kokemusasiantuntijuuteen sitä kieltävämmin, mitä lähemmäs se tulee oman ammatillisuuden ydintä, yleistä lääketieteellistä tietoa. Aineistossa tulee esiin näkemys, että potilaita tavatessaan kokemusasiantuntijat eivät saisi antaa toisille lääketieteellistä ohjetta tai neuvoa. Perusteluksi useissa haastatteluissa esitettiin kokemusasiantuntijuuteen sisältyvä suuri riski väärän tiedon levittämiseen. Tämä johtuu kertojien mukaan siitä, että kokemusasiantuntijoilla maallikkoina ei ole ammattilaisten kaltaista kykyä arvioida informaation oikeellisuutta.

Perinteisen asiantuntijuuden vahva asema lääke- ja hoitotieteen saralla ei kuitenkaan tarkoita, etteikö kokemusasiantuntijuudella olisi siellä lainkaan paikkaa. Kokemusasiantuntijoita toimii sairaaloissa ja heitä myös koulutetaan terveydenhuollon organisaatioissa 
(ks. Hämeenaho ym. 2019). Potilaiden kanssa toimiessaan kokemusasiantuntijan toimialue rajautuu niin aihepiirin kuin paikan kautta. Fyysisesti kokemusasiantuntijuus on rajattu erilleen hoito- tai lääketieteen ammattilaisten alueilta siten, että heidän pitää pysytellä aulatiloissa, joissa he voivat tavata potilaita tai muuta yleisöä.

Ja esmes tää kokemusasiantuntija mikä meillä kävi, siitä heräs taas tosi semmonen positiivinen palo, oli älyttömän hyvä asiakkaitten kanssa siellä organisaation (yksilöivä nimi poistettu) odotusaulassa kyseli kommentteja miten on päässy ja ihan tämmösiä asioita ja sit hän seuras mitkä kaikki siellä toimii tai ei toimi ja mihin tulee kiinnittää huomiota, siis ihan kulkuväylät, ni se oli älyttömän hyvä (H5 ryhmä 1, verkosto)

Terveydenhuollon ammattilaisten keskusteluissa kokemusasiantuntijoiden hyödyntäminen tulee esille juuri erilaisten asiakastilojen ja rakennusten suunnittelussa ja muokkaamisessa potilaiden kannalta toimiviksi. Tällöin kokemusasiantuntijuus suuntautuu kuitenkin suunnittelijoihin, hallintohenkilöstöön ja päättäjiin, eikä terveyden- tai sairaanhoidon henkilöstön osaamiseen ja työhön.

\section{Eettinen vartijuus}

Kolmas analyysissä tunnistettu, kokemusasiantuntijuuteen suhteutuva ammatillisen asiantuntijuuden muoto nimettiin eettiseksi vartijuudeksi. Tällä korostamme sitä, että painotus on käytännöllisesti ja konkreettisesti eettisyyden valvonnassa. Tästä asiantuntijuuden muodosta puhutaan aineistossa liittyen muun muassa työtehtäviin, ohjeistuk- siin, pelisääntöihin, julkisuuteen, riskeihin ja uupumiseen.

Eettisestä vartijuudesta puhuttiin kaikissa haastatteluissa. Järjestöorganisaatio, jossa kokemusasiantuntijatoimintaa on kaikkein eniten, ei poikennut tässä suhteessa muista, mutta sen edustajien puheessa eettinen vartijuuden kuvailu oli rikkaampaa ja moniulotteisempaa kuin muissa haastatteluissa. Analyysissä paikannettua eettisen vartijuuden sisältöä avaamme seuraavassa mahdollisimman yksityiskohtaisesti tarkastelemalla toiminnan kohteita ja muotoja sekä toimintakehyksiä.

Laajimmillaan eettinen vartijuus kohdistuu koko organisaation toimintaan. Organisaatiota voidaan kehittää sillä periaatteella, että kokemusasiantuntijuus ja -asiantuntijat otetaan huomioon kaikessa ja organisaatioon luodaan tästä näkökulmasta asianmukaisia ohjeistuksia. Eettisten ohjeiden ja pelisääntöjen laadinta, organisaation toiminnan tarkkailu sekä erilaisten käytäntöjen käyttöönotto kuuluvat ammattilaisille.

Eettisyyden vartiointi koko organisaation tasolla takaa sen, että erilaiset ja eri taustoista tulevat kokemusasiantuntijat voivat hyvin ja että toiminta voi jatkua ja kehittyä kestävällä pohjalla. Lopulta eettisyys perustuu siihen, että ammattilaiset ovat myös omien toimintatapojensa asiantuntijoita ja kriittisiä arvioitsijoita.

Haastattelija: Mitä te ajattelette, että mitä se ammattilaiselta vaatii kun hän toimii $y$ hteistyössä kokemusasiantuntijoiden kanssa H2: Asennetta. Aattelen et kunnioittavaa asennetta 
H1: (...) ei järkyty tai pelästy tai että pystyy hallitsemaan myös ne omat tunteet mitä siitä tulee ja suostuu myös sitte niihin (ryhmä 7, järjestö)

Eettisyyteen organisaatiotasolla kuuluu yleisten linjausten tekeminen siitä miten, milloin ja missä laajuudessa kokemusasiantuntijoiden työpanosta hyödynnetään. Kokemusasiantuntijat nähdään tärkeinä organisaation ja yleisemmin edustamansa asian voimavaroina, joten heitä pitää suojata liialta rasittamiselta. Toisaalta kokemusasiantuntijoita ei myöskään pidä jättää liian vähälle huomiolle, jotta näiden arvokas asiantuntijuus ei jää käyttämättä.

Portinvartijana ammattilainen estää kokemusasiantuntijalta pääsyn jonnekin tämän suojaamiseksi. Etenkin media edustaa potentiaalista pahaa,jonka portista sisään käyminen voi johtaa ennalta arvaamattomiin vahingollisiin seurauksiin kokemusasiantuntijan tai tämän läheisten elämässä. Tästä syystä lapsia ei päästetä lainkaan julkisuuteen ja täysiikäisen kokemusasiantuntijan kanssa käydään vakavaa keskustelua siitä, mihin omasta kokemuksesta julkisuudessa puhuminen voi johtaa. Kokemusasiantuntijat kertovat asioista, joista media saa tehtyä "sosiaalipornoa", ellei ammattilainen pysty varmistamaan, että aikeet ovat asialliset.

No just näistä esimerkiks millä tavalla tullaan julkisuuteen ja mitä voidaan julkisuudessa niinkun vaikka se kokemusasiantuntija itse haluaisi jotakin kertoa ja sitten että se täytyy tarkistaa tarkasti ettei koidu myöhemmin hänelle haittaa. Se on kovin houkuttelevaa se julkisuus ja tietty semmonen glamouri mikä voi sillä hetkellä imee. Sitten meiän tehtävä on niitä rajoja jotenkin rakentaa tai ainakin tarjoilla (H1 ryhmä 7 , järjestö)

Ammattilaisen asiantuntijuuteen kuuluu ymmärtää vaarat ja tarjota tai rakentaa rajoja kokemusasiantuntijan ympärille tämän suojelemiseksi. Työntekijällä on vastuu päättää, mihin osallistutaan ja millaisissa tilaisuuksissa kokemusasiantuntijat ovat mukana. Eräässä organisaatiossa kokemusten julkistamisesta aiheutuva riski on pyritty minimoimaan rakentamalla yhteinen, eettisesti kestävä tarina. Tällä tarinalla kokemusasiantuntija edustaa julkisuudessa paitsi itseään, niin myös laajempaa taustaryhmäänsä. Samalla yksilöiden kokemukset ovat suojassa yleiseltä riepottelulta.

Suodattajana toimiessaan ammattilainen on kokemusasiantuntijan mukana erilaisissa tilanteissa ja tilaisuuksissa varmistamassa, että ne sujuvat eettisten periaatteiden mukaisesti. Toisin kuin portinvartijuudessa, pyrkimys ei ole suojata kokemusasiantuntijaa täysin joltakin tapahtumalta tai tilanteelta, vaan tarkoituksena on tarkkailla ja puuttua tarvittaessa. Käytännössä ammattilainen voi seurata taustalla esimerkiksi kokemusasiantuntijan työskentelyä chatissa. Tavallinen suodattajana toimimisen paikka on puhetilaisuus, johon kokemusasiantuntija on kutsuttu esiintymään joko ammattilaisille tai suurelle yleisölle. Yleisöä voidaan ohjeistaa siitä, millainen on sopiva käyttäytyminen suhteessa kokemusasiantuntijaan esimerkiksi kertomalla, miten hänen esitystään voi kommentoida. Jos tilanne ohjeistuksista huolimatta uhkaa mennä väärään suuntaan, puuttuu suodattaja siihen. Puhetilaisuuden jälkeen suodattamista voivat vaatia yleisöltä kerätyt palautteet, joihin on kenties kirjoitettu 
esiintymässä olleelle kokemusasiantuntijalle sopimattomia asioita. Ääripäässä suodattaminen voi tarkoittaa kaiken keskustelun kieltämistä kokemusasiantuntijan esityksen yhteydessä:

\section{(...) kyllä aina siihen porukkaan mahtuu vaikka minkälaista, että siis jossain vai- heessa mää rajasin sen, että kaikki palaut- teet jostain puhujakeikoilta tulee mulle, ei koskaan suoraan kenellekään puhujalle. Ja joskus on pitäny rajata sillä tavalla että ei mitään kysymyksiä saa esittää (H1 ryhmä 8 , järjestö)}

Kokemusasiantuntijan suojelijana ja tukijana ammattilaisen pitää ymmärtää mikä on kokemusasiantuntijan edun mukaista ja tämän jälkeen varmistaa edun toteutuminen. Tämä ei ole kuitenkaan helppoa, sillä jokaisella kokemusasiantuntijalla on henkilökohtainen tahti, jonka mukaisesti hänen valmiutensa kehittyvät yhä vaativampiin tehtäviin ja tilanteisiin. Ammattilaisen tulee olla sensitiivinen ja tarkka, sillä organisaatiolla ja sen työntekijällä on vastuu siitä, missä vaiheessa voi mistäkin kipeästä asiasta puhua ja milloin kokemusasiantuntija voi olla omassa asiantuntijaroolissaan.

Kokemusasiantuntijan tehtävissä toimivaa pitää suojella erilaisilta vaaroilta, kuten väsymiseltä ja siltä, ettei tämä jo rikkoutuneena ihmisenä rikkoudu lisää. Erilaisten tilaisuuksien rasittavuutta ja kuluttavuutta kokemusasiantuntijoille tulee vähentää suunnittelemalla ja harjoittelemalla ne hyvin etukäteen ja purkamalla tuntemukset yhdessä jälkikäteen. Lisäksi pitää varmistaa, ettei kokemusasiantuntijalla ole ylipäänsä liikaa työtehtäviä kokemusasiantuntija-asemaansa liittyen. Konkreettisesti pelisääntöjen toteutumista valvotaan esimerkiksi niin, että päätökset tilaisuuksiin osallistumisista tehdään yhdessä kokemusasiantuntijan kanssa kohtuullisen harkinta-ajan puitteissa.

Suhteiden vartijana ammattilainen valvoo, kuka on kenenkin kanssa yhteydessä. Kokemusasiantuntijan roolista neuvon antaminen toiselle ihmiselle sisältää ison vastuun, mistä syystä pitää tietää kuka ohjeen saa ja ettei ohje ole tälle vaaraksi. Ammattilaisen tulee siksi miettiä toisen ihmisen suojaamisen kysymyksiä tarkkaan.

Jopa jotkut ammattilaiset voivat yllättäen olla enemmänkin vaarallisia kuin hyödyllisï kokemusasiantuntijalle. Ammattilaisten aiheuttamalle vaaralle voi altistua etenkin suuremmissa tilaisuuksissa, joissa kokemusasiantuntijat käyvät puhumassa:

\section{(...)Hyvinkin ikäviä juttuja ollu täs vuosien mittaan ammattilaisten niinku tosi epäasial- lisesta kohtelusta, et ne unohtaa ammatti- lainen sen että se on oikeesti oman elämän avaa, se on todella kunnioitettavaa mutta se ei sitte saattaaki kohdata aika koviaki puu- koniskuja (H2 ryhmä 7, järjestö)}

Lopuksi eettisen vartijan tehtävä on suojella muita ihmisiä kokemusasiantuntijoilta. Näin eettisen vartijan huomio suuntautuu myös päinvastaiseen suuntaan kuin aiemmissa osatehtävissä. Etenkin, jos kuulijoina ovat omat asiakkaat, on ammattilainen vastuussa heidän hyvinvoinnistaan. Maallikoilta puuttuva ammatillinen osaaminen itsensä suojelemiseen altistaa kokemusasiantuntijan esiintymisen haittapuolille. 
Tilanteita, joissa muut ihmiset voivat joutua mieltä järkyttävien ja pahoittavien tilanteiden eteen kokemusasiantuntijan takia, ovat ennen kaikkea yleisötilaisuudet. Useissa haastatteluissa kerrottiin esimerkkejä kokemusasiantuntijoista, joiden huono valmistautuminen tai puutteellinen tilannetaju on johtanut muita ihmisiä kiusallisiin tai vaarallisiin tilanteisiin. Myös aihe itsessään voi olla kuulijakunnalle sopimaton. Niin sosiaali- kuin terveysalan ammattilaiset nostivat esiin useissa puheenvuoroissa erityisesti päihdekysymysten kokemusasiantuntijoiden tuottaman uhkan muille ihmisille:

H2: näist päihdepuolen tulee mieleen et sieltähän nyt voi tulla helpostikin lisää tietoa, sehän voi tulla kaikkialla, että hän kertookin hyviä vinkkejä vahingossa siellä ja niistä lähteeki sit et aivan, tätä en oo vielä kokeillu

H5: Ja esimerkiks siinä viiltelyssä niin siitähän on jonkin verran että tällaset vertaiskokemukset saattaakin saada sen tarpeen vaikka päälle, että joku tekee niin uudestaan (...) (ryhmä 1, verkosto)

Oman tehtävänsä vaatimuksiin perehtymätön kokemusasiantuntija voi olla uhka myös palveluille. Kokemusasiantuntijaksi ryhtyvän henkilön pitää olla riittävän sujut oman kokemuksensa kanssa, jotta hän kykenee toimimaan kyseisessä tehtävässä. Hänen pitää ymmärtää oma roolinsa muiden auttamisessa, eikä hoitaa itseään tai ajaa omaa asiaansa. Omaan agendaansa perustuvia, väärïä neuvoja jakamalla hän johtaa muita ihmisiä harhaan tai ajattelemaan palveluvastaisesti. Ammattilaisten vahva näkemys oli, että muun muassa tämän ongelman selättämiseksi kokemusasiantuntijoille tarvitaan koulutusta, joka sisältää eettisten toimintaperiaatteiden läpikäyntiä.

\section{JOHTOPÄÄTÖKSET JA POHDINTA}

Kiinnostus kokemusasiantuntijuutta kohtaan on kasvanut viime vuosina niin käytännön auttamistyössä kuin tutkijoiden ja päättäjien keskuudessa. Ammattilaisten näkökulmat ja etenkin kokemusasiantuntijoiden mukaan tulon myötä asiantuntijatyössä tapahtuvat muutokset näyttävät kuitenkin jääneen varsin vähälle huomiolle. Tässä tutkimuksessa lapsi- ja perhepalveluiden ammattilaisten asiantuntijuutta tarkastellaan kolmen laajan, eri tavoin kokemusasiantuntijuuteen suhteutuvan ja suhtautuvan asiantuntijuuden muodon kautta.

Perinteinen asiantuntijuus pysyttelee asiantuntijan ja asiakkaan erillisissä rooleissa, joissa kokemusasiantuntijuuden toimintakenttä on suppea. Perinteiseksi asiantuntijuudeksi kutsumamme asiantuntijuuden muoto on aiemmassa tutkimuksessa liitetty erityisesti lääketieteelliseen asiantuntijuuteen ja lääkäriprofessioon (Saarinen 2010; Bennetts ym. 2011; Oborn ym. 2019). Myös tässä tutkimuksessa kriittisin suhtautuminen kokemusasiantuntijuuteen löytyi juuri terveydenhuollon kontekstista, jossa sen kuvattiin liittyvän etenkin lääkäreiden asenteisiin.

Järvinen $(2016,59)$ toteaa fasilitoinnin ja valmentamisen olevan osa uudenlaista, asiakkaiden osallistumista hyödyntävää työskentelyä. Toisaalta sosiaalityössä ja kuntoutuksessa on jo pitkään korostettu niin asiakkaan subjektiutta kuin ammattilaisen tukea ja kunnioitusta 
asiakkaan ratkaisuja ja omaa elämää koskevaa tietoa kohtaan. (ks. Rissanen 2015, 164; Järvinen 2016.) Tässä tutkimuksessa asiakkaiden osallistuminen heidän oman asiantuntijuutensa kautta liitetään yhteistyöasiantuntijuudeksi nimettyyn asiantuntijuuden muotoon. Ammattilaiselle yhteistyöasiantuntijuus luo uudenlaisia tai kenties vahvistaa olemassa olevia rooleja, mutta se näyttää myös perustuvan ammatillisen asiantuntijuuden osittaiselle menettämiselle tai sen merkityksen vähenemiselle.

Kolmas havaituista asiantuntijuuden muodoista, eettinen vartijuus, liittyy tutkimuksessamme vahvasti kokemusasiantuntijuuden luomiin tarpeisiin ja haasteisiin. Kirkegaard $(2020,19) \mathrm{ku}-$ vaa asiakastyön muutokseen kuuluvan ammattilaisten siirtymistä taka-alalle, ohjaamaan tilanteita hienovaraisesti. Samalla tavoin tässä tutkimuksessa nähdään, miten ammattilaiset häivyttävät omaa asiantuntijuuttaan ja antavat tilaa asiakkaiden kokemusasiantuntijuudelle. Taustalla pysyttelevän ammattilaisen roolit kiteytyvät eettisessä vartijuudessa, jossa ammattilaisen pitää kyetä monitahoisiin ja tarkkoihin arviointeihin eettisyyden näkökulmasta. Näin juuri eettisen vartijuuden voi tulkita olevan se tapa, jolla lapsi- ja perheammattilaiset tuottavat kokemusasiantuntijoiden kanssa työskentelyssä uutta ammatillista asiantuntijaroolia aiempien roolien oheen tai niiden tilalle.

Vaikka hallinnon ja palveluiden kehittämisen nähdään vaativan asiakasosallisuuden lisäämistä (Kallinen ym. 2018, 15), ei kokemusasiantuntijuutta vielä hyödynnetä laajasti lapsi- ja perhepalveluissa. Jos kokemusasiantuntijuuden käyttöä halutaan lisätä, on tärkeä selvittää myös ammattilaisten näkökulmia ja etenkin sitä, millaista asiantuntijuutta ammattilaiset jatkossa tarvitsevat kokemusasiantuntijoiden kanssa työskennellessään. Tällä mahdollistetaan osaltaan kokemusasiantuntijuuden saaminen luontevaksi ja kaikkia osapuolia hyödyttäväksi osaksi palveluja.

\section{KiRJALlisuUs}

Alasuutari, Pertti (2011) Laadullinen tutkimus 2.0. Tampere: Vastapaino. https://www.ellibslibrary.com/reader/9789517685030. Luettu 3.6.2020.

Arnetz, Judith \& Winblad, Ulrika \& Arnetz, Bengt \& Höglund, Anna (2008) Physicians' and Nurses' Perceptions of Patient Involvement in Myocardial Infarction Care. European Journal of Cardiovascular Nursing 7 (2), 113-120. https://doi. org/10.1016/j.ejcnurse.2007.05.005

Barkman, Johanna \& Inkinen, Helena \& Isoniemi, Sami \& Vario, Pipsa (2017) Muutosvoimaa! Kohti nuorten kokemusasiantuntijuutta lastensuojelussa. Opas- ja käsikirjat 3. Jyväskylä: Pesäpuu ry.

Bennetts, Wanda \& Cross, Wendy \& Bloomer, Melissa (2011) Understanding consumer participation in mental health: Issues of power and change. International Journal of Mental Health Nursing 20 (3), 155-164. https://doi.org/10.1111/ j.1447-0349.2010.00719.x

Boshuizen, Henny P.A. \& Bromme, Rainer \& Gruber, Hans (2004) On the long way from novice to expert and how travelling changes the traveler. Teoksessa Henny P. A. Boshuizen, Rainer Bromme \& Hans Gruber (toim.) Professional Learning: Gaps and Transitions on the Way from Novice to Expert. Dordrecht: Kluwer Academic Publishers, 3-8. https:// doi.org/10.1007/1-4020-2094-5_1

Bozeman, Barry (1993) Theory, wisdom and the character of knowledge in public management: a critical view of the theory-practice linkage. Teoksessa Barry Bozeman (toim.) Public management. The 
state of the art. San Francisco: Jossey-Bass Publishers, 27-40.

Caduri, Aviva \& Weiss-Gal, Idit (2014) Social Workers Who Work With and Without Volunteers: Comparison of Perceptions, Organizational Culture, Training and Experience. British Journal of Social Work 45 (8), 2458-2475. https://doi. org/10.1093/bjsw/bcu028

Carr, E. Summerson (2010) Enactments of Expertise. Annual Review of Anthropology 39 (1), 17-32. https://doi.org/10.1146/annurev.anthro.012809.104948

Dieterich, Anja (2007) The modern patient -Threat or promise? Physicians' perspectives on patients' changing attributes. $\mathrm{Pa}-$ tient Education and Counseling 67 (3), 279-285. https://doi.org/10.1016/j. pec.2007.03.017

Glenton, C. \& Colvin, CJ \& Carlsen, B. \& Swartz, A. \& Lewin, S. \& Noyes, J. \& Rashidian,A. (2013) Barriers and facilitators to the implementation of lay health worker programmes to improve access to maternal and child health: qualitative evidence synthesis (Review). The Cochrane Collaboration https://www.ghdonline. org/uploads/Lay_Health_Workers_Cochrane_Review.pdf . Luettu 11.5.2020. https://doi.org/10.1002/14651858. CD010414

Haapakoski, Kaisa \& Kasila, Kirsti \& Kettunen, Tarja (2018) Kokemusasiantuntijoiden sisäänpääsy sairaalaorganisaatioon. Päiväkirja-analyysin yhtymäkohdat Norbert Eliasin teoriaan. Janus 26 (1), 40-56. https://doi.org/10.30668/janus.64210

Hietala, Outi \& Rissanen, Päivi (2015) Opas kokemusasiantuntijatoiminnasta: kokemusasiantuntija - hoidon ja avun kohteesta omien kokemusten jakajaksi sekä palveluiden kehittäjäksi. Helsinki: Kuntoutussäätiö \& Mielenterveyden keskusliitto.

Hirschovits-Gerz, Tanja \& Sihvo, Sinikka \& Karjalainen, Jarno \& Nurmela, Anna (2019) Kokemusasiantuntijuus Suomessa. Selvitys kokemusasiantuntijakoulutuksen ja -toiminnan käytännöistä. Työpaperi nro 17. Helsinki: Terveyden ja hyvinvoinnin laitos.

Hämeenaho, Pilvi \& Rask, Linda-Maria \& Kasila, Kirsti \& Kettunen, Tarja (2019)
Terveydenhuollon ammattilaisten ja asiakkaiden näkemyksiä kokemusasiantuntijan vastaanottotoiminnasta terveysasemalla. Tutkiva Hoitotyö 17 (4), 22-29.

Jakonen, Mikko (2017) Vastatieto - Tulevaisuuden asiantuntijuutta etsimässä. Eduskunnan tulevaisuusvaliokunnan julkaisu 1/2017. Helsinki: Eduskunta.

Järvinen, Margaretha (2016) Expertise and Ambivalence in User-Focused Human Service Work. Teoksessa Jaber Gubrium, Tine Andreassen \& Per Solvang (toim.) Reimagining the Human Service Relationship. New York: Columbia University Press, 59-78. https://doi.org/10.7312/ gubr17152-004

Kallinen, Kati \& Laitinen, Merja \& Lantela, Lauri \& Leinonen, Jaana \& Nikupeteri, Anna \& Nurmi, Henna \& Turunen, Tuija (2018) Lasten, nuorten ja perheiden osallisuus monitoimijaisen yhteistyön mahdollisuuksina ja haasteina. Teoksessa Päivi Petrelius \& Pia Eriksson (toim.) Uudistuva lastensuojelu - kohti asiakkaiden ja ammattilaisten yhteistoimintaa. Työpaperi 32. Helsinki: Terveyden ja hyvinvoinnin laitos, 14-23.

Kirkegaard, Sine (2020) The Everyday Drama of Coproduction in Community Mental Health Services: Analyzing Welfare Workers' Performance as the "Undercover Agent". Symbolic Interaction 43 (3), 428-451. https://doi. org/10.1002/symb.478

Kortteisto, Tiina \& Laitila, Minna \& Pitkänen, Anneli (2018) Attitudes of mental health professionals towards service user involvement. Scandinavian Journal of Caring Sciences 32 (2), 681-689. https://doi.org/10.1111/scs.12495

Légaré, France \& Ratté, Stéphane \& Gravel, Karine \& Graham, Ian (2008) Barriers and facilitators to implementing shared decision-making in clinical practice: $\mathrm{Up}$ date of a systematic review of health professionals' perceptions. Patient Education and Counseling 73 (3), 526-535. https:// doi.org/10.1016/j.pec.2008.07.018

McCann, T.V. \& Baird, J. \& Clark E. \& Lu, S. (2008) Mental health professionals' attitudes towards consumer participation in inpatient units. Journal of Psychiatric and Mental Health Nursing 15 (1), 10-16. https://doi.org/10.1111/j.1365- 
2850.2007.01199.x

McLaughlin, Hugh (2009) What's in a Name: 'Client', 'Patient', 'Customer', 'Consumer', 'Expert by Experience', 'Service User' - What's Next? The British Journal of Social Work 39 (6), 11011117. https://doi.org/10.1093/bjsw/ bcm155

Meriluoto, Taina (2018) Making expertsby-experience - Governmental ethnography of participatory initiatives in Finnish social welfare organisations. Jyväskylä: University of Jyväskylä.

Needham, Catherine (2007) Realising the Potential of Co-production: Negotiating Improvements in Public Services. Social Policy \& Society 7 (2), 221-231. https:// doi.org/10.1017/S1474746407004174

Noorani, Tehseen (2013) Service user involvement, authority and the 'expert-byexperience' in mental health. Journal of Political Power 6 (1), 49-68. https://doi. org/10.1080/2158379X.2013.774979

Nowotny, Helga (2003) Democratising expertise and socially robust knowledge. Science and Public Policy 30 (3), 151-156. https://doi. org/10.3152/147154303781780461

Oborn, Eivor \& Barrett, Michael \& Gibson, Sarah \& Gillard, Steve (2019) Knowledge and expertise in care practices: the role of the peer worker in mental health teams. Sociology of Health \& Illness 41 (7), 1305-1322. https://doi. org/10.1111/1467-9566.12944

Palukka, Hannele \& Tiilikka, Tiina \& Auvinen, Petra (2019) Kokemusasiantuntija mielenterveys- ja päihdepalveluissa - osallisuuden mahdollistaja vai osallistamispolitiikan väline? Janus 27 (1), 21-37. https://doi.org/10.30668/janus.66252

Pohjola, Pasi \& Pitkänen, Niina \& Koivisto, Juha (2015) Sosiaalityön tietokäytännöt vuorovaikutteisina vaihtoalueina. Janus 23 (2), 175-178.

Pösö, Tarja (2018) Experts by Experience Infusing Professional Practices in Child Protection. Teoksessa Asgeir FalchEriksen \& Elisabeth Backe-Hansen (toim.) Human Rights in Child Protection. Cham: Springer Nature, 111128. https://link.springer.com/chapte r/10.1007\%2F978-3-319-94800-3_6. Luettu 10.8.2020. https://doi. org/10.1007/978-3-319-94800-3_6

Rissanen, Päivi (2015) Toivoton tapaus? Autoetnografia sairastumisesta ja kuntoutumisesta. Kuntoutussäätiön tutkimuksia 88. Helsinki: Kuntoutussäätiö.

Roberts, Glenn \& Wolfson, Paul (2004) The rediscovery of recovery: open to all. Advances in Psychiatric Treatment 10 (1), 37-48. https://doi.org/10.1192/ apt.10.1.37

Saarinen, Arttu (2010) Suomalaiset lääkärit ja Suomen Lääkäriliitto osana hyvinvointivaltiota ja sen terveyspolitiikkaa. Sosiaali- ja terveysturvan tutkimuksia 114 . Helsinki: Kelan tutkimusosasto.

Solbjor, Marit \& Steinsbekk, Aslak (2011) User involvement in hospital wards: Professionals negotiating user knowledge. A qualitative study. Patient Education and Counseling 85 (2), e144-e149. https:// doi.org/10.1016/j.pec.2011.02.009

Soronen, Kari (2020). Tunnekokemukset osana kokemusasiantuntijaksi kehittymistä. Janus 28 (1), 60-76. https://doi. org/10.30668/janus. 70425

Sosiaali- ja terveysministeriö (2009) Mielenterveys- ja päihdesuunnitelma. Mieli 2009 -työryhmän ehdotukset mielenterveys- ja päihdetyön kehittämiseksi vuoteen 2015. Sosiaali- ja terveysministeriön selvityksiä 3 .

Sosiaali- ja terveysministeriö (2016). Lapsi- ja perhepalveluiden muutosohjelma. Sosiaali- ja terveysministeriön raportteja ja muistioita 29.

Storm, Marianne \& Hausken, Kjell \& Knudsen, Knud (2011) Inpatient service providers' perspectives on service user involvement in Norwegian community mental health centres. International Journal of Social Psychiatry 57 (6), 551-563. https://doi. org/10.1177/0020764010371270

Sulik, Gayle A. \& Eich-Krohm, Astrid (2008) No longer a patient: The social construction of the medical consumer. Teoksessa Susan Maizel Chambré \& Melinda Goldner (toim.) Patients, Consumers and Civil Society. Bingley: Emerald Group Publishing Limited, 3-28. https://doi.org/10.1016/S10576290(08)10002-X

Tambuyzer, Else \& Pieters, Guido \& Van Audenhove, Chantal (2014) Patient in- 
volvement in mental health care: one size does not fit all. Health Expectations 17 (1), 138-150. https://doi.org/10.1111/ j.1369-7625.2011.00743.x

Toikko, Timo (2016) Becoming an expert by experience: An analysis of service users' learning process. Social Work in Mental Health 14 (3), 292-312. https:// doi.org/10.1080/15332985.2015.1038 411
Valtonen, Anu \& Viitanen, Meiju (2020) Ryhmäkeskustelut laadullisena tutkimusmetodina. Teoksessa Anu Puusa \& Pauli Juuti (toim.) Laadullisen tutkimuksen näkökulmat ja menetelmät. Helsinki: Gaudeamus. https://www.ellibslibrary. com/reader/9789523456167. Luettu 3.6.2020. 